\title{
NEEDS ANALYSIS ON THE IMPROVEMENT OF ENGLISH FOR INFORMATICS COURSES BASED ON THE PERCEPTION OF NON-ENGLISH TEACHERS OF STATE POLYTECHNIC OF MALANG
}

\author{
Atiqah Nurul Asri ${ }^{1}$, Farida Ulfa ${ }^{2}$, Satrio Binusa Suryadi ${ }^{3}$ \\ State Polytechnic of Malang \\ atiqah.nurul@polinema.ac.id
}

\begin{abstract}
The purpose of the present study was to reveal the needs analysis commissioned by the Information Technology Department regarding the non-English teachers' perceptions on the teaching and learning practices of the English language in the department. The study employed an online questionnaire and interview to 23 IT teachers. The questionnaire covered the five categories, namely English Language Teaching at IT Department, Language Skills and Components, Teaching Learning Activities, Teaching Skills, IT related topics should be included and Assessments. It used Likert Scale ranging from 1-4 showing disagree to really agree. In addition, the interview utilized a prompt designed beforehand to get the necessary advice to formulate appropriate English language materials for IT students. The results revealed that the teachers needed a more efficient course design and development covering the design of the course syllabus, the creation of activities and materials, and the evaluation of learner progress. They are expected to provide insights as the basis for the improvement both on the teaching preparation and practices.
\end{abstract}

Keywords: needs analysis, ESP Classrooms, IT Department, vocational education

\section{INTRODUCTION}

English as one of the most spoken language worldwide has been included in every curriculum in Indonesian education ranging from elementary school until higher education. State Polytechnic of Malang is one of the higher education institutions which focuses on technical and vocational education and training also facilitates the students to improve their English competences by requiring English as part of the curriculum of each departments.

In line with this, English language is treated as English for Specific Purposes (ESP) since the aim is to facilitate students to be able to use English in a particular specialization, not to mention in Information Technology (IT) Department. In this department, English language is taught under such courses names as English for Informatics 1 and 2. Thus, all language skills (speaking, listening, reading, and writing) and components (pronunciation, vocabulary, and grammar) are taught within IT contexts. It means that in teaching materials, all those language skills and components are trained and developed under such topics as Computer Users and Apps, Computer Architecture, Multimedia, Networking, 
Website, IT Careers, and the like. The idea is that the students will be able to implement those skills in the world of working. In other words, all the materials are designed in such a way to suit the students' needs.

The advanced development in IT fields has influenced the teaching English practices as well. The ESP teachers need to regularly develop the materials and the methods to keep up with the advancement. In this case, one way to do this is by conducting needs analysis to the improvement of the teaching practices by distributing questionnaire to IT teachers to ask for their professional opinions towards the practices.

Seeing the needs of the students to survive in professional setting, it is then significant to map their specific needs through needs analysis. These needs, as mentioned previously, are very specific, and therefore they should establish the content of any course. In line with this, Hutchinson and Waters (1987) describe the importance of satisfying learner's needs and interests since it is closely related with the students' motivation and achievements. Consequently, needs analysis is significant. To narrow down, in language teaching, the needs analysis is widely used for a wide range of purposes. In this study, the needs analysis is used to find out the language skills required by the students to perform a particular role in a particular setting, such as web developer, software engineer, project manager, IT help desk, and many more. Needs analysis is also significant in ensuring the existing course adequately has already addresses the needs of the students. Furthermore, it can also help determine the problems of any particular students during the course. Thus, this paper is aimed at conducting needs analysis for the improvement of the teaching practices in IT Department of State Polytechnic of Malang.

\section{English for Specific Purposes (ESP) in Technical and Teaching Vocational Education and Training (TVET)}

The examination of language and learning needs (i.e. "needs analysis" or "needs assessment") within the realm of language teaching has been the object of a significant number of studies (Huhta et.al., 2014). The mastery of English for professional purposes in reality is supported by Hutchinson and Waters (1987) stating that English has been long and widely used as the means of communication in the field of technology and commerce. This means inside both business and commerce world, most communication uses English as its means. Furthermore, this also affects the skills and competence for job requirements seek in the global market. As a result, teaching and learning goals in colleges, polytechnic in particular, needs to meet the demand in the global market to ensure the students can function properly when they are set into specific professional settings. It is then obvious to see that English mastery is prerequisite for an individual in order to survive the educational and professional functions.

The need to properly function professionally by having English mastery is often seen in the job vacancy requirements. This means that the better the English mastery is, the wider opportunity for an individual for possible promotion to open. Many polytechnics or technical and vocational education and training have been long realized this demand and therefore teach their students the types of English language, namely English for Specific Purposes (ESP) and not General English (GE) taught at colleges or universities. 
One of ESP characteristics as stated by Johns and Price-Machado (2001) is that it is specifically designed in such a way to suit the needs of the students and is in line with their "disciplines, occupation, or activities". Thus, when designing materials for IT students, for instance, the topics should be related to issues on IT. The activities provided for the students are also in IT settings; take for instance, telling a process on how to install software, giving suggestions on hardware problems, analyzing a good e-commerce website, setting a network, and comparing two peripherals. In other words, the activities given reflect real life situations and use authentic materials. This, in turn, also influences the course, the choice of materials, as well as the teaching method applied in the classroom.

Ahmed (2014) argues that "ESP focuses on when, where and why students need the language either in study or workplace contexts". Besides, he explains that teaching materials and methods are determined by "how language is used in the particular contexts the students will work or study in". In short, ESP emphasizes on activities where language is used in a context or "situated language use". Accordingly, the ESP teacher/course developer needs to determine "what the language-based objectives of the students are in the target occupation or academic discipline and ensure that the content of the ESP course works towards them".

Furthermore, Ahmed (2014) describes two main elements in the ESP teaching practices: the teacher and the materials. The one eligible to teach is professional teacher whose expertise is in teaching English for any professions and designing teaching materials using the content materials presented by the expert of that subject in order to develop students' language competence in authentic and real situation settings. Meanwhile, the teaching materials are those related with the use of English for certain professions which stimulate the students to use their background knowledge relevant to their major along with the academic skills in dealing with all sorts of authentic information in their profession.

Cong and Wang (n.y) mention that TVET (Teaching Vocational Education and Training) is a part and a special type of higher education that involve the study of technologies and related sciences. The objective is to bring up application-oriented skills. It means that the needs for studying based on practices as needed in professional settings is considered more significant than theoretical study since the goal is to prepare the students' skills required for professional functions in industry. In line with TVET, the English mastery for professional purposes can also be seen in ESP as its goal is to equip the students with adequate English skills to compete and survive in the employment global market.

\section{Recent Teaching English Language Practices in the IT Department at State Polytechnic of Malang (Self-Reflection)}

\section{Teachers Competence}

There are 3 English language teachers in this department (each of whom teaches between 10-12 credits) whose teaching experience is ranging from 3 until 13 years. One of whom has been professionally certified since 2012, two of them scored 875 for TOEIC issued by ITC (International Test Center), and all of them got master degree in English Language Teaching at a renowned university in 
Malang. Thus, based on the criteria mentioned by Ahmed (2014), all of them are qualified in teaching ESP classes.

\section{Teaching Materials}

The teaching materials have been used are compiled from any resources, most of which are taken from available English for IT textbooks and the like, published by such eminent publishers as Oxford, Cambridge, and Longman. English language skills and components are taught within any related IT topics adopted from those books. Since there are two courses namely English for Informatics 1 and 2; therefore, the topics are arranged in such a way that those found in English for Informatics 1 module is quite easier that those found in English for Informatics 2 module. The arrangements of the topics are based on the level of their difficulties (after consulting them with the IT teachers). Moreover, each module and any relevant materials are given per unit according to the Lesson Plan and uploaded to the department designed LMS (Learning Management System) every week. All students have already had the accounts and can download them. Moreover, on the first week, the students are given the course contract showing all information related with the course objectives, topics, evaluation, and schedule.

\section{Teaching Methods}

The teaching method applied in the teaching and learning activities are varied from lecturing, presenting specific IT-related topics both individually and in a group, role play, case study, and group discussions. Besides, the methods are also related to the integration of ICT into the teaching learning activities in the classroom including asking students to create such projects as web folio, wiki, and digital storytelling and present them in the classroom and upload them as well.

Furthermore, teaching strategies such as flipped classroom is also implemented. In this method, students are asked to learn about the materials provided in the LMS or Edmodo prior the class, so that when they come to the class, they have already understood what is going to discuss and do the assignment in the class.

So far, up to the last semester, English for Informatics courses have often been named as the most favorable courses in the IT Department. It has been proven by the feedback given by the students in the end of the semester (through the questionnaire both paper and online based).

\section{Teaching Evaluation}

The students are evaluated based on their performance on the tests (midterm test, final-term test, quizzes), presentation (individual, group), role play, and assignments (homework, paper-based assignments), and projects like web folio, wiki, digital storytelling, and so forth. So the evaluation is in form or both spoken and written ones. In addition, the final test term is usually in form of online examination (using an online exam app designed and developed by the department) consisting of multiple choices questions covering all the topics in each module. 


\section{Challenges}

There have been challenges faced by the ESP teachers while teaching English in the department. First, there was a crucial issue especially when the department was about revising the implemented curriculum. There was a different point of view in teaching English within IT contexts due to the lack of understanding about ESP caused some argumentations about the new curriculum. The developer had thought that General English was supposed to be taught in the IT Department, not like what it had been implemented. However, when the problems were solved by giving understanding that implementing ESP concept is relevant and suitable with the students' needs. Secondly, if ESP is implemented, it is likely that all language skills and components are taught in an integrated way. Yet, despite its importance, yet English courses are taught only for 3 semesters (3 x 50 minutes a week). Therefore, the teachers need to find strategies to help the students develop their language skills. One way is by utilizing the technology both tools (computer, smart phones, and the internet) and materials (both paper-based and online-based found in the web and downloaded via app stores) and integrated it into the classroom activities. Third, there is somehow lack of supports by IT teachers especially in pronouncing IT related terms since they tend to pronounce them with accents or regardless whether it is correctly pronounced or not. As we know that in most applications, English words are available and commonly used, but the other teachers are likely ignore them. Accordingly, the students make the same mistakes as the IT teachers even though in English class the teacher has corrected it over and over. Finally, it is still difficult to find proper texts related with IT topics as well as supporting textbooks (the teachers should buy them online and sometimes they are not reasonable). Thus, the ESP teachers are required to be creative in designing the materials and they need to always update their knowledge about IT related terms, topics, and trends by reading a lot of IT books, share them with the IT teachers if having difficulties in understanding them, and attend conferences, seminars, and workshops relevant to their teaching practices.

\section{METHOD}

\section{Reasons}

The need analysis is conducted because of the following reasons:

1. As a basis to update materials for teaching and learning. The results of this study will be used as a basis of updating the teaching materials. It is hoped that by analyzing the responses given by Non-English teachers of the IT Department, provides a better insight in offering the students with the latest issues related to IT development and are relevant to the student's needs.

2. The need for self-reflection and evaluation whether the teaching and learning process has been carried out as it is planned in the syllabus, Lesson Plan, etc. As mentioned previously, there will be an upcoming revision in the curriculum. The results of needs analysis here is used as a basis of revision needed for a better syllabus, and other teaching documents and to check whether what had been developed, has been doing in the classroom, and most significantly, what will be updated in line with the students need at present and in the future. 
3. The need for self-reflection and evaluation whether what has been taught in the classroom reflect students' needs as both needs as students, and their future needs as professionals. The department has been regularly doing tracer study to find information whether what has been taught in the classroom can be applied in their workplace. Some of the Non-English teachers are involved in this activity, and therefore are considered able to provide suggestions on what needs to be update related with the materials, and the teaching and learning practices in the classroom.

4. The need to ensure that implementing ESP in this department and thus not providing the students with merely General English is relevant in supporting the institution as the one practicing Technical and Vocational Education and Training.

The method to conduct the analysis is by giving online questionnaire and conducting interview to IT teachers. The questionnaire is given online and has got 23 respondents. It consists of questions comprising 5 categories, namely English Language Teaching at IT Department, Language Skills and Components, Teaching Learning Activities, Teaching Skills, IT related topics should be included and Assessments. It uses Likert Scale ranging from 1-4 showing disagree to really agree. In addition, interview is conducted using a prompt designed beforehand to get the necessary advice as needs analysis to formulate appropriate English language materials for IT students.

\section{RESULTS AND DISCUSSION}

Based on the results of the interview, it can be broken down into several things related to the teaching of English in accordance with the referred question to the IT teachers. The points are as follow:

1) The topics for discussion in English class should be about the latest trends in the field of IT. It aims at providing an insight to the students about the current issues that are in line with the subject that they are studying at the moment. By doing so, the students will be familiar with all kinds of issues existing today where it is needed later, or when they get to work. For example: the students are asked to create a discussion on a project they have made in a group discussion.

2) The topics being discussed in the English Courses are considered more applicable when they are related with what the students are studying in other classes, in different courses i.e. IT-related courses in particular, at the same semester. For example, in the English Course, the students are discussing a topic on programming, and at the same semester, they are taking courses in Programming. It will help them to understand the subject matter easier since they can easily relate to it. Another example is that the students can be assigned to discuss a specific matters related to programming by looking for references on the forum or website programmer who speak English to enrich their experience in learning the English language. The aim is to ensure that students are familiar with the use of English in an online forum. Simultaneously, it provides a hands-on experience to the students to interact with native speakers which in turn will gain more confidence in the language classroom practice. 
3) The importance of increasing student learning motivation is by creating a supportive learning atmosphere. Some things that can be pursued are to create attributes marker on campus using English. Take, for instance, making bilingual announcements, both in Bahasa Indonesia and English, or making written rules and regulations applied in the faculty in English. In addition, it is recommended to create a program called "English Day" that requires the whole department, i.e. teachers, administrative staffs, and students in particular use English in a particular time. It aims to foster students' interest and motivation in learning English by setting up a versatile atmosphere in the department namely "Kampung Inggris JTI" in a weekly basis.

4) The needs to encourage students to participate in both national and international competitions. This could be one of the effective ways that can be pursued to foster students' motivation by enrolling them in competitions. Automatically, in turns, it will spur their enthusiasm to study harder because there are responsibilities given to them. Moreover, the motto "Sometimes you win. Sometimes you learn." needs to be highlighted since the initial goal is to learn.

Moreover, the results of the questionnaire are depicted below. In terms of the English language teaching in the department, 17 out of 23 respondents (73.9\%) really agree that English language teaching is relevant to the learner's needs and 14 of them really agree that the teaching has already been adjusted to the IT contexts.

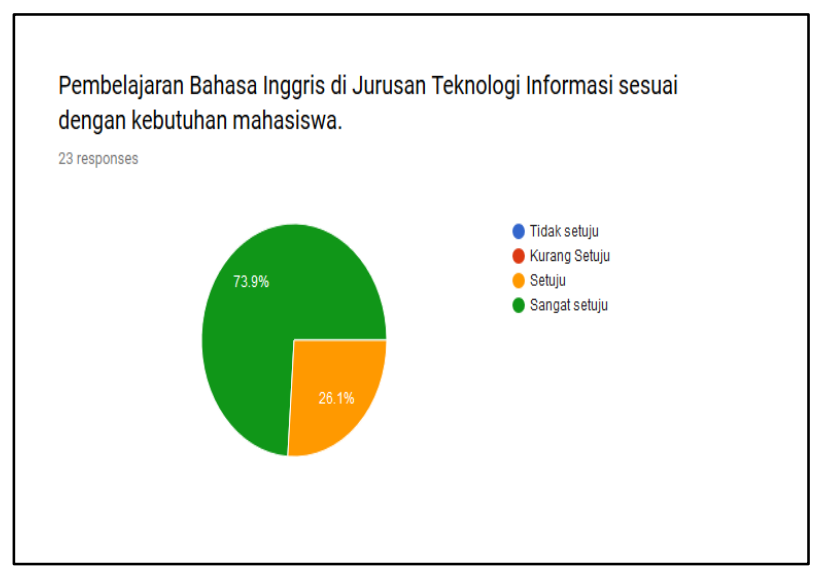

Fig. 1: The relevance of English language teaching on student's needs.

Figure 2 shows that 19 respondents $(82.6 \%)$ state that English language teaching in this department is important to prepare the students for the world of working in the future; however, 11 of them $(47.8 \%)$ really agree that the activities provided are in accordance with the real life situations. 


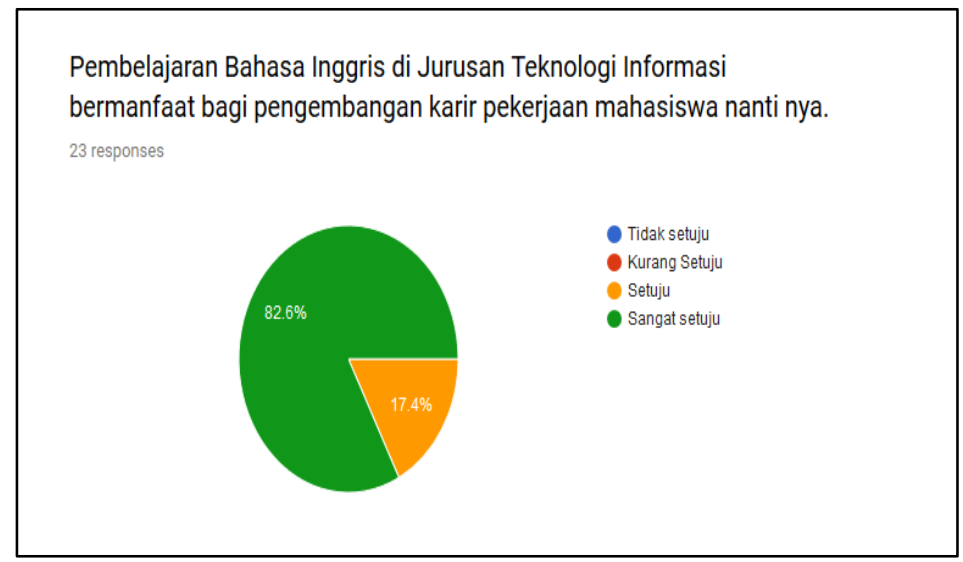

Fig. 2: The relation of English language teaching and students' career in the future.

Regarding to the language skills, most of them really agree that the ESP teachers should focus more on Listening (52.2\%), Speaking (65,2\%), and Reading $(69,6 \%)$. Whereas, $52.2 \%$ respondents agree that they should focus on Writing. In addition, in terms of language components, most respondents (52.2\%) really agree that teaching vocabularies are substantially emerging.

The next part is about teaching and learning activities. Figure 3 shows that according to the IT teachers $(65.2 \%)$, individual presentation, role play related to the real life situation, and mini projects are likely practically suitable for the students' needs. Another appeal activity is asking the students to find a solution over an IT related problems or a case study (60.9\%). Moreover such activities as group discussion and presentation (47.8\%) are slightly more favorable than lecturing $(43.5 \%)$.

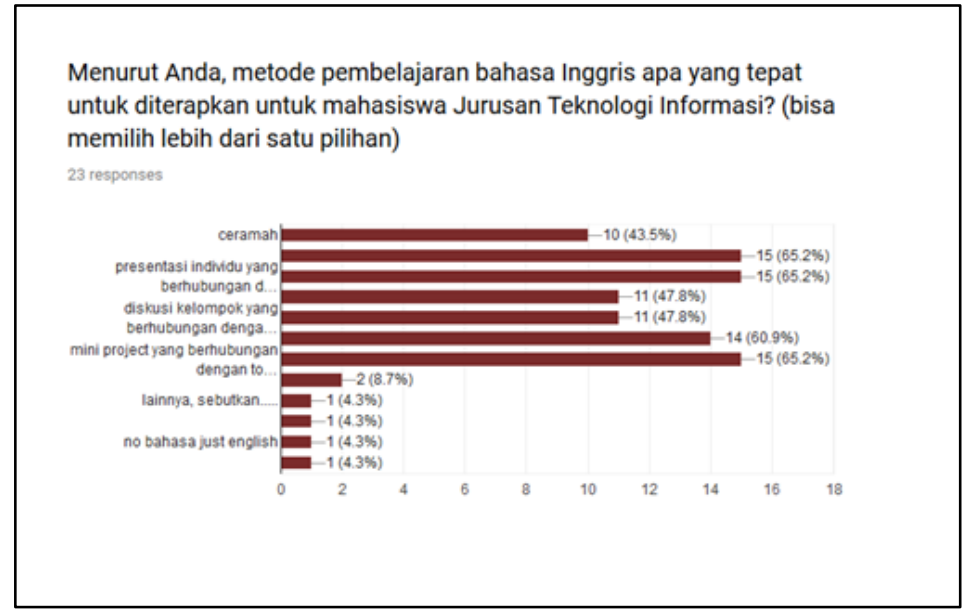

Fig. 3: Teaching methods for the IT students.

The next part of the questionnaire is about the list of IT related topics should be included in the module. The topics given in the questionnaire are taken from the available designed and applied modules. From the responses, it can be concluded that the most suggested topics are programming, computer application, careers in IT, and recent development in IT (60.9\%). The next suggested topics are networking and e-commerce $(56.5 \%)$ and database, computer security, and 
multimedia (52.2\%). The less suggested topics are website and IT support staff (43.5\%) and e-publishing and work health and safety (30.4\%). Moreover, one respondent states that all the topics mentioned are all suggested and the other one adds a topic related to IT public relation.

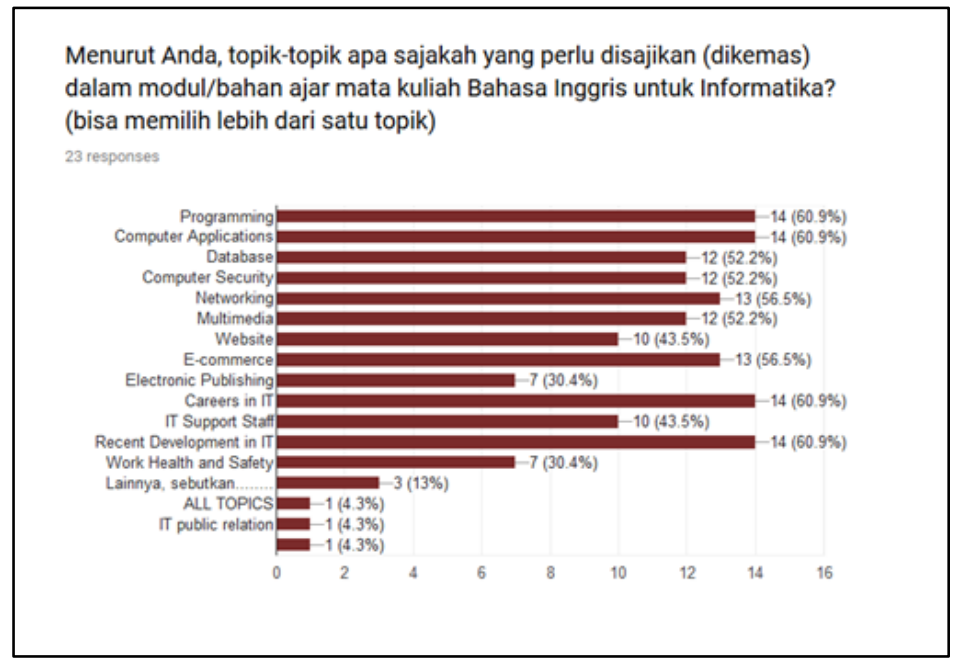

Fig. 4: The relevance of the topics on the English courses for IT.

In terms of assessments, the respondents are given lists of the usual ones conducted. To the IT teachers' perception, the most engaging assessments are in form of individual presentation (91.3\%). The next types are consecutively listed as follow, essay (69.6\%), multiple choices (56.6\%), group presentation $(52.2 \%)$, and true/false $(30.4 \%)$.

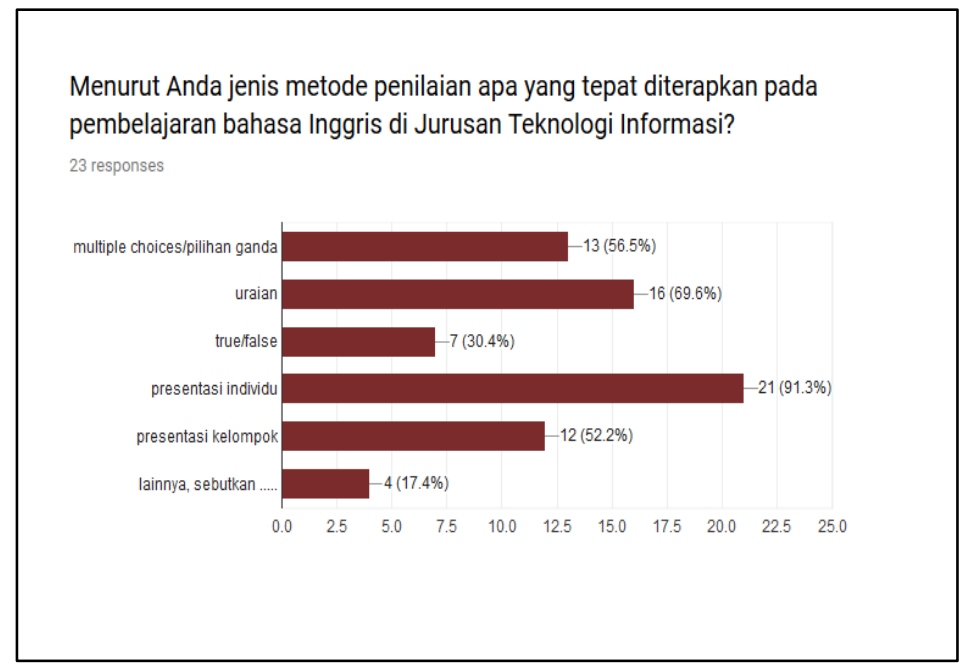

Fig. 5: Type of assessments for the IT students.

From the data taken from both interview and questionnaire, it can be deduced that the teaching and learning practices in the IT department, which is implementing ESP method is mostly appealing to facilitate the students to develop their language skills and components. The classroom activities are regarded relevant to suit the students' needs since they are in somehow close to real life situations. Thus, it may be said that ESP is closely significant with the concept of 
technical and vocational education (Flowerdew, 2013) in this case, an IT related job. The improvement lays upon the needs to provide students with updated materials, thus regularly revising the materials, especially reading texts, is likely substantial. Furthermore, the students also needs to be constantly encouraged and motivated as well as given opportunities to explore their English skills more, not to mention all the staffs in the department (teacher and administrative ones).

These results are consistent with the findings of the study by Lee (2016) investigating the learners' perspectives of perceived needs on their ESP (English for Specific Purposes) course at a university of technology. They indicated that the extent of ESP needs perception held by the students was very high, about $80 \%$ of students thought ESP courses are useful and helpful for the future job. In addition, the English skill needed most was writing skill and students with the higher English proficiency held significant difference from the lower on interest in English learning.

The results are also relevant to the study by Indrasari (2016) revealing that it is crucial to design a language teaching for the students of the Physics Education Department with relevant contexts in order to gain effective and beneficial teaching and learning process for their professional purposes.

\section{THE IMPLICATIONS FOR THE IMPROVEMENT}

Based on the results. It implies that for further materials development, the syllabus and curriculum development, as well as the teaching practice, there are some things that needs to be highlighted:

1. There is a need to update some parts of the learning materials. In general, the learning materials used in the classroom has already reflected the suggestions given by IT teacher. However, there are also a few things that needs update. For example, in English for Informatics 1 Module, there is a topic on Computer Architecture that discuss on the way to read an advertisement that is related to PC specifications. The PC description used here is from an old-fashioned PC, from which far in its time is a high-end PC with Intel Pentium 4 processor attached. This needs to be updated with the latest specs in the market to let the students know how advanced the technology is. Moreover, it is also a good idea to compare the latest specs of PC or laptop with the older version to provide references on how technology has changed vastly.

2. Topics on IT-related courses offered in the same semester will help students understand the subject matter better since the background knowledge can help them easily relate it. Assigning students to join an IT forum with English as a means of communication can also enrich their experience and in turn will boost their confidence in the language classroom practice.

3. One of the most feasible ways to encourage students in using English is by getting them used to in using it through the visuals. Getting them used to reading signs written in English can be a great assistance. Students can also be encouraged by immersing themselves with international students, since the department initiating the program for international class since this semester. This will for sure boost their confidence in using more English in a daily basis. By getting enough confidence, further, "Kampung Inggris JTI" can be executed.

4. Participating in both national and international competitions can also be used as a means of encouraging students to be eager to learn and practice English 
more. This should be emphasized with the motto on "Sometimes you win. Sometimes you learn." since the initial goal is learning not just for winning purposes as winning is considered as a bonus.

\section{CONCLUSION}

From the discussion above, it can be inferred that the implementation of ESP in the IT department is well executed and considered relevant with the students' needs in the world field as well as supporting the institution as the one practicing Technical and Vocational Education and Training (TVET). Moreover, in order to meet the needs of students in vocational learning which includes applied theory and applied mastery is important. The regularly updated materials are necessary since the IT field is developed very fast. Moreover, the needs to give more exposures is also appealing to deploy the students' motivation and courage in improving their competences. The improvement from the perspectives of the teachers was needed concerning language aims, teacher input, procedure, learner output, learning outcomes, evaluations, language level required, preparation and materials, duration and suggestions for follow-up work was still needed. Therefore, the role of ESP teachers is a vital point in helping students to nurture their abilities in English. They should have a sound understanding of the course content because the ESP teacher is not mastered in the field, but in teaching English. This is done by the support of the content teachers, i.e. IT teachers.

A further similar study is suggested to be highly valuable to needs analysis researchers in any learning context (either occupational or academic). More particularly, it will be an invaluable resource to English language practitioners in Indonesia's higher education contexts who have been forced to match their courses and teaching practices with the tenets of the Kerangka Kualifikasi Nasional Indonesia (popularly known as KKNI), a framework of working qualification classes which juxtaposes, equalizes, integrates education sector and training and working experience in order to grant working recognition of competences in accordance to the position of employment in different sectors (Hafidz, 2014).

\section{REFERENCES}

Ahmed, Mohammad Kaosar Ahmed. (2014). The ESP Teacher: Issues, Tasks and Challenges, English for Specific Purposes World, Issue 42, Vol. 15, 2014. Retrieved from www.esp-world.info .

Basturkmen, H. (2010). Developing Courses in English for Specific Purposes. Basingstoke: Macmillan.

Flowerdew, L. (2013). Needs analysis and curriculum development. In B. Paltridge, \& S. Starfield (Eds.), The handbook of English for specific purposes (pp. 325-346). WestSussex: Wiley-Blackwell.

Hafidz, M.A. (2014). The Role Self Access Language Learning Center (SALLC) Materials In Achieving KKNI Based Curriculum Learning Outcomes. EJournal UNP. ISBN: 978-602-17017-3-7, pp. 328-340. 
Huhta, M., Vogt, K., Johnson, E., and Tulkki, H. (2013). Needs Analysis for Language Course Design. A Holistic Approach to ESP. Cambridge: Cambridge University Press.

Hutchinson, T. and Walter, A.(1987). English for Specific Purposes: a Learning centered Approach, Cambridge: Cambridge University Press.

Indrasari, N. (2016). English for Specific Purposes: A Need Analysis at The Second Semester of Physics Education Students of IAIN Raden Intan Lampung in The Academic Year of 2015/2016. English Education: Jurnal Tadris Bahasa Inggris, Vol 9 (1), pp. 161-172.

John and Price-Machado. (2001). English for Specific Purposes (ESP): Tailoring Courses to Students Needs - and to the Outside World. In Celce-Murcia, M (Ed). Teaching English as a Second or Foreign Language $\left(3^{\text {rd }} \mathrm{Ed}\right)$, pp. $43-$ 55. Boston: Heinle \& Heinle.

Lee, C. (2016). Principles and Practices of ESP Course Design-A Case Study of a University of Science and Technology. International Journal of Learning, Teaching and Educational Research, Vol. 15, No. 2, pp. 94-105. 